\title{
Taking Digital Media to School: A Sociosemiotic Perspective on Educational Portals
}

\author{
Maria Agustina Sabich ${ }^{1,2,3}$ \\ ${ }^{1}$ Social Communication Sciences, Faculty of Social Sciences, University of Buenos Aires, Buenos Aires, Argentina \\ ${ }^{2}$ Secretary of Science and Technique (SECyT/FSOC/UBA), University of Buenos Aires, Buenos Aires, Argentina \\ ${ }^{3}$ Media Semiotics, University of Buenos Aires, Buenos Aires, Argentina \\ Email: msabich@sociales.uba.ar
}

Received 5 April 2016; accepted 24 April 2016; published 29 April 2016

Copyright (C) 2016 by author and OALib.

This work is licensed under the Creative Commons Attribution International License (CC BY).

http://creativecommons.org/licenses/by/4.0/

(c) (i) Open Access

\begin{abstract}
In this article we propose to analyse some of the discursive strategies implemented in Educ.ar, the national educational portal of Argentina. The methodology used contemplates Eliseo Veron's theory of social discourses, which focuses on the social processes of meaning making, as well as the second trichotomy propounded by Charles Sanders Peirce and some of the conceptual contributions from the fields of Educational Technology and Communication-Education. Our general hypothesis is based on the idea that, initially at least, the use of educational portals may be inefficient because of the lack of structure, organization, and quality in the resources available from the digital platform Educ.ar. In this sense, on the one hand, we might even say that educational portals are not being used to their full potential, since analogue devices such as textbooks still have greater legitimacy as educational tools, while on the other hand, the digital media are still seen as if they only could be related to fun or entertainment. Therefore, in this paper we will describe the formal aspects in the design of Educ.ar in order to shed some light on its characteristics and to enable its better appropriation by the whole educational community. In the end, we will try to suggest some considerations to improve the formal structure of this educational portal.
\end{abstract}

\section{Keywords}

Educational Portals, Sociosemiotic, Pedagogical Discourses, Digital Media

Subject Areas: Education

\footnotetext{
“The power of practical discourse on educational technology has silenced other voices that try to explore its conflicts and untie their knots, to recognize its limits and its possibilities, to express the discomforts, the
} 
needs, the resistances and also the innovations.”

\section{Eva da Porta [1]}

\section{Introduction: Some General Considerations on the Digital Platform Educ.ar ${ }^{1}$}

The educational portal Educ.ar (Figure 1 and Figure 2) is a virtual site created in 2000 by the Ministry of Education of Argentina and has integrated the Latin American Network of Educational Portals (RELPE) since August 2004. The emergence of this platform was due to the idea of integrating Information and Communication Technologies (TIC) all over the national education sector ${ }^{2}$.

The importance of studying this website relies on the fact we understand that digital media contribute to the construction of identities, and that is the reason why we assume that it is necessary to analyse the various discursive operations and strategies used by teaching platforms. Although in recent years Latin American national states have been carrying out certain programmes to incorporate educational technologies in classrooms (for example, Conectar Igualdad in Argentina, Enlaces in Chile, Huascaran in Peru), as Dussel and Quevedo [2]
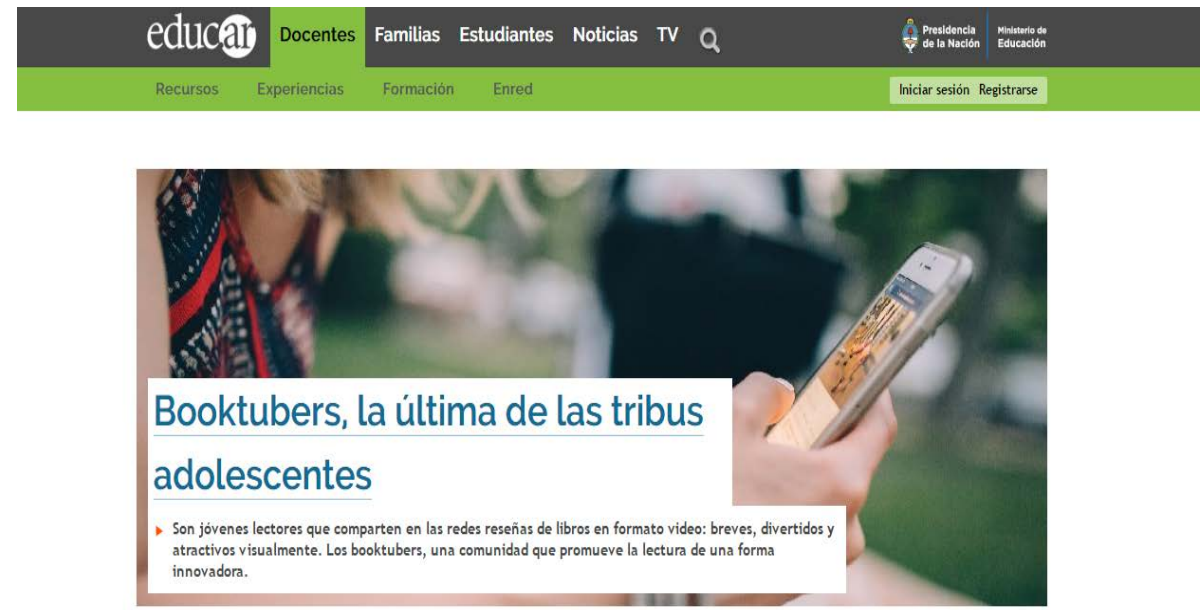

Figure 1. Screenshot of Educ.ar's homepage.

iEl futuro ya llegó! Participamos de la charla «El futuro del futuro», a cargo de @bilinkis https://t.co/2l6kBKG2Zj https://t.co/wPnaHfAEGR | o1/Apr/2016 14:45:53
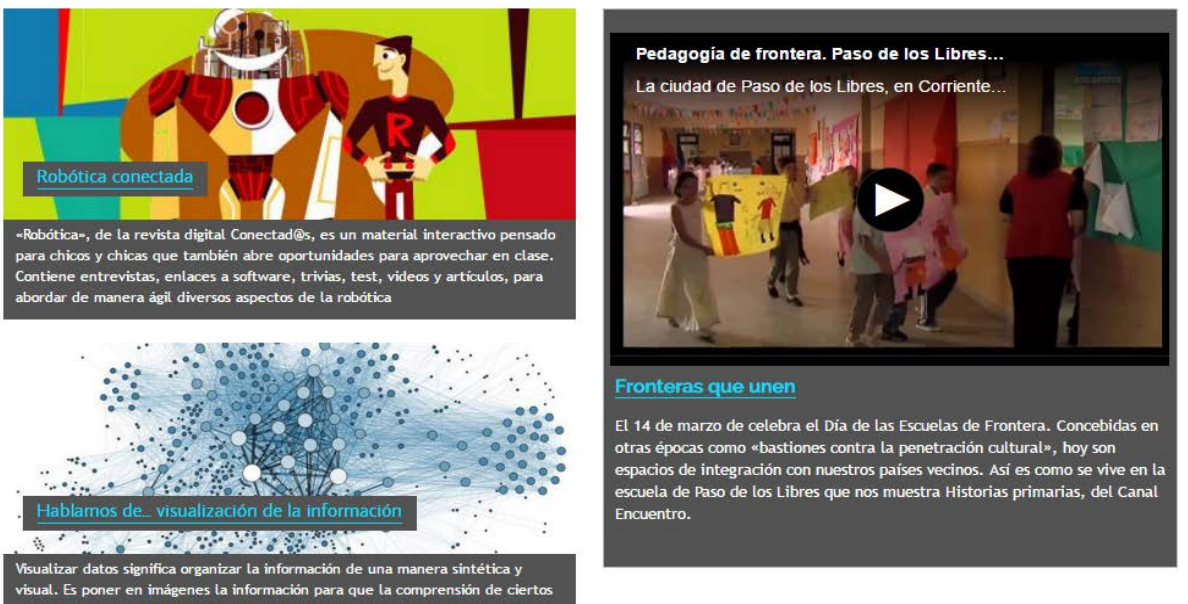

Figure 2. Screenshot of Educ.ar's homepage.

${ }^{1}$ Click the following link to visit this website: $\underline{w w w . e d u c}$.ar

${ }^{2}$ The platform is also related to the development of other state programmes such as Conectar Igualdad, Conectate, Deportv, Pakapaka and Canal Encuentro. 
note, we could say that there still are a lack of training, an unstable connection and an inadequate public policy which would not be allowing a genuine inclusion of technology in education.

In addition, Argentinian researcher Puiggrós [3] points out that contemporary school is off-centered, scattered and weakened due to a constant tension between neoliberal and interventionist policies. In this sense, knowledge is presented in a fragmented way because school has lost its image as the "sole transmitter" of truth, a process strengthened by the appearance of other educational variables relating to mass media and new technologies. In effect, mass media and new technologies are currently destabilising the social function of school as the only source of valid knowledge.

Our research hypothesis is based on two assumptions: in the first place, we believe that those interactive and multimedia features (Scolari [4]) which characterise the Internet as "new" media are not being exploited effectively in the design of educational portals; in the second place, we claim that uses of educational portals are inefficient because of the lack of structure, organization, and quality in the resources hosted on its digital platforms. We could even say that educational portals are not being used to its full potential, since analogical devices such as textbooks still have greater legitimacy as educational tools, on the one hand, while on the other hand the digital media are still seen as if they only could be related to fun or entertainment. That is the reason why we might think that the design of educational portals and other pedagogical platforms is not exploited enough at present.

Finally, our interest in carrying out this research responds to the fact that there are few studies ${ }^{3}$ on educational portals within a discursive perspective. This could be seen as a limitation, especially if we consider the huge presence of digital media at schools and analogue media restraints regarding their possibilities as teaching and learning tools (Castellón \& Jaramillo [9]).

\section{Methodology: Eliseo Veron's Theory of Social Discourses as a Source of Inspiration}

The sociosemiotic methodology of research used in this study contemplates Eliseo Veron's [10] Theory of Social Discourses (TDS), which consists of "the combination of hypotheses about the operating modes of social semiosis", focusing on "the significant dimension of social phenomena" [10]. In particular, we will conduct an analysis on production to delimit "a field of possible meaning effects" ${ }^{\text {[10] }}$ that is, to infer a set of rules applied to a "discourse" or to a "discourse package" at a specific socio-historical moment.

TDS $^{5}$ is the study of social phenomena as involving "processes of meaning making”. In this sense, the Theory of Social Discourses claims that all social processes can be defined by a set of socio-historical conditions, and that the traces of those processes appear in texts under the form of marks. We should notice that the recognition of those traces will depend on the symbolic capital of the analyst. Verón also says that "every manifestation of meaning implies a material manifestation”, in other words, our analyses always start off by seeking configurations of meaning (fragments of the social semiosis) inscribed in a material support: "the material support, understood as a discourse or a discourse combination, is nothing but a spatio-temporal configuration of meaning".

To expand the formulations of the Argentinian theorist, as suggested by Verón himself, we also pick up on the second trichotomy propounded by Peirce [11] — composed of icon, index and symbol, who refers to "three significant orders operating in the social semiosis": the iconic order (analogy), the indicial order (contiguity) and the symbolic order (conventionality). Peirce defines the icon as "a sign determined by its dynamic object by virtue of its own inner nature". At the same time, he understands the index as "a sign determined by its dynamic object by virtue of being in a real relation with it". And, finally, he describes the symbol as "resulting from a social convention" [11].

We will also use methodological tools proposed by the Argentinian researcher Steimberg [12] [13] in relation with the three levels of textual construction this author suggests: the rhetorical level, the thematic level and the enunciative level. As this semiotician notes, these three levels do not constitute "a system of mutually exclusive relations among them" [12], but a system of intermingled relations. Following the proposals of Bremond and Durand, Steimberg indicates that the rhetorical level should not be understood as something that corresponds to ornamental elements of discourse, but as an essential dimension of any act of meaning making that covers all of

\footnotetext{
${ }^{3}$ See, for example, the studies of Maggio [5], Sevillano García [6], Martínez-Méndez et al. [7] and López Guzmán [8], which address general descriptions of educational portals focusing on their main properties, functions, advantages and disadvantages.

${ }^{4}$ Which, in fact, could be corroborated through reception analysis.

${ }^{5}$ To extend Verón’s [15] ideas on digital media see: La semiosis social 2: ideas, momentos interpretantes.
} 
the mechanisms involved in the production of any kind of text (for example, sequence organization, incidental music, adjectives used, among others). Furthermore, based on the proposals of Segre, Steimberg defines the thematic level as the situations and actions that respond to representations schemes historically related and previous to the text: the themes are those stereotyped elements that show semantically what the discourse is about and that are generally not evidenced in the surface of the text; for its part, the motifs appear in a greater number and can be observed in the surface of the text, for example under the form of various types of characters (the "fool", the "hero", the "villain") or situations (such as happy endings). Finally, following Maingueneau and Verón, Steimberg defines the enunciative level as "the meaning effect of semiotic processes that consist on building a communicative situation on a text through devices that could be linguistic or extra-linguistic (...). The definition of this situation could include (...) the relation between a transmitter and a receiver that are implicit figures, not necessarily customisable” [12].

\section{A Digital Picture Conditioned by the School Year: Educ.ar Homepage's Configuration}

According to the first observations that we could make of the Educ.ar homepage, we noticed that digital hypertext structure gets expanded and diversified, as well as it becomes more complex. As Scolari [14] says, "if the text was a solid entity in the past, with well-defined limits, today it becomes a flow that allows us to think of it in terms of liquid textuality" [14], which unfolds without a beginning or an end ${ }^{6}$.

Now, the question we have to ask is the following: what types of limits are operating through such diversification? In the first place, we can observe that Educ.ar homepage has a dynamic based on a vertical structure and it involves various "tabs". Certainly, this structure is in accordance with common features of the Internet. On this page, there are a multiplicity of content such as literary works, news, educational videos and other elements that links the Educ.ar website to social networks. There are also promotions of some specific science magazines for teachers and certain television channels that belong to the national state (DeporTv or Pakapaka). But content provided by this educational portal is only "restricted" to the national state and it does not include resources from other Latin American countries.

The logic of this website could be associated with the discursive configuration of digital newspaper, where we can find "highlighted areas" and a hierarchical organization that distinguishes primary or "relevant" content from "secondary" or additional content. This procedure — that implicitly guides and directs users' readings—could be demonstrated not only by the point size or the image size, but also by the specific use of colors. For example, the most important or the most recent resources—images or videos-are located first, expanding all over the page and involving a variety of colors and graphic styles. However, items that could be located within the "secondary or additional content" usually appear at the end of the homepage in small caps, as well as they use a relatively "simple" graphic style based on opaque or dark colors like black, white and gray. In this space, portal information appears summarised and we can find data related to platform's general and legal functioning, likewise its links to other platforms such as Twitter, Facebook or YouTube ${ }^{7}$.

In order to describe the homepage of Educ.ar website, we have to mention that it always changes according to the cycles of the academic year. Therefore, its content could be organised into three semantic fields: start of classes, duration of classes and finish of classes. At the beginning of the school year, we can see that there usually are some photographs related to this fact in the educational portal (including schedules, useful data and some educational materials to prepare lessons). During the school year, there are some diversified components, such as interviews with writers or specialists, educational games, tools for improving the use of technologies in the classroom, educational news and resources to teach some historic dates. Finally, during the school break, images all over the digital platform tend to show some extra-curricular issues related to tourism, road safety, leisure time and holiday experiences narrated by the students themselves. To illustrate this idea, we chose the cover page corresponding to school break time:

From Figure 3, we can see that the picture ${ }^{8}$ shows a vehicular traffic which uses metonymy to represent the idea of "space saturation" and "vehicular chaos". Also, this picture is accompanied by the following note: "On

\footnotetext{
${ }^{6}$ The "liquid textuality" of the Internet was also addressed by Giammatteo \& Albano [16].

${ }^{7}$ For future research based on reception analysis it would be interesting to study the uses that the educational community makes of the virtual sites, establishing relations between educational portals and other digital platforms.

${ }^{8}$ The "picture" is actually a screenshot of the platform.
} 


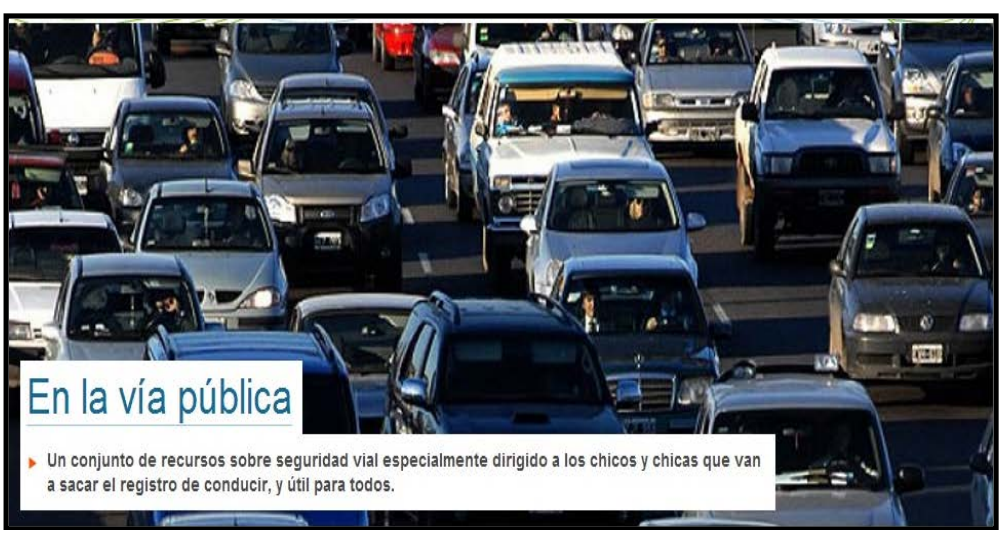

Figure 3. Screenshot of Educ.ar's homepage. Road safety.

the public road. A set of resources about road safety specially aimed at boys and girls who will get their driving record soon and useful for everyone".

As we can see, there are some confusing discursive constructions on this resource: on the one hand, there is a certain logic of discontinuity between the homepage and the educational content hosted, since the last one is located on the "teachers section" but, at the same time, it is aimed (discursively) at students: "A set of resources about road safety specially aimed at boys and girls (...)". On the other hand, the note includes a minor sentence ("On the public road") which enunciative modality is closer to the journalism discursivity than to the pedagogical discursivity. We believe that this logic of discontinuity may produce an uncertainty effect on those who surf the website. Possibly, this inconsistency is due to the fact that the educational portal homepage has not a "neutral" or a "generic" page where "common documents" for all kind of users could be incorporated.

Additionally, Educ.ar provides some materials developed by the Ministry for Interior and the Ministry of National Education, such as teaching programmes, guide questions, vehicular laws and conceptual definitions about traffic. On the section about "driver education", we can observe a strong presence of the indexical component as there is a huge presence of "life colors" such as green, yellow, blue and pink. Also, the internal organization of the document implies "boxes" that separates content, so in formal terms we found an attractive organization to "captivate" receptor's attention.

However, the structural logic of the website has some problems. For example, we still notice there are logical discontinuities between the resources hosted and the section on which they are located, because the mixing of materials aimed at students and materials aimed at teachers. Furthermore, resources provided on the educational platform do not develop the interactive features that digital devices present to users. On the contrary, these resources are distributed linearly and sequentially, that is, in the same way they could be displayed in textbooks. In addition to this, there is no "formal" or "stylistic" distinction: some of them use similar thumbnails (small images), while their names do not express their specificity.

Under the same section, we can also find an educational videogame which-through a "Question and Answer" modality -introduces the topic of road safety. This videogame articulates "information" with "entertainment" and it also interpellates users' proactivity, taking advantage of the technical possibilities offered by the Internet and a type of genre that involves high levels of social consumption. However, it is important not to fall into a "typical celebration" (Buckingham [17]) of educational technology because this is an area that has certain limitations and content is not necessarily neutral nor reliable. In this particular case, the national state- that takes a position as an educator agent and, therefore, as an enunciator-leaves a mark that circumscribes what is considered as "legitimate" and "worthy" to be taught to the educational community, for example during school holidays, as well as it installs behavior patterns and indicates "how to be a good citizen" or a "responsible driver". In this sense, we can notice the presence of a strong argumentative discourse that builds the figure of a citizen-addressee committed with the national vehicular safety.

\section{The Homepage and Its Addressees: Limits and Possibilities of Technology Inclusion}

A distinctive feature that characterizes the educational portal—in some way presented as "prototypical" of the 
discursivity of the Internet-is the existence of tabs, which are used for organising information according to the users' interests. In the case of Educ.ar, we found five different types of tabs: three that distinguish types of users ("students", "families" and "teachers"), one for "news" and another one for "TV". Within them, each addressee has a specific group of tabs which are identified, in turn, with different colors and cover images (green for teachers, violet for families and blue for students): this demarcation is done using different "tones" and could be related to the idea of creating a quick search effect, thanks to which users could "identify" or "associate" different educational resources.

Now, the questions we must ask is the following: in which case this rhetoric-enunciative organization facilitates search for information? Does it promote a "nimble search" or a "prudent search"? Does it promote the exercise of a critical reflection on the materials available? Based on these questions, we will now see how discursive organization works on the different users' pages $^{9}$.

\subsection{The Teacher-Addressee}

The teacher-addressee section is indicated with the colour green and it includes the following tabs: "resources", "experiences", "calls" and "training". At the rhetorical level, the picture helps to make a metaphor based on a metonymic operation: education as building. This meaning effect responds to the appearance of certain elements in the page that refer to building materials such as bricks, a compass and a tape.

From Figure 4, we can see that the picture is accompanied by the following note: Time to plan. Besides being an administrative requirement, why and what for design a lesson plan? Here, the linguistic text invites teachers to appreciate planning and not to think of it only as a bureaucratic requirement. In this sense, the figure of the teacher-addressee is drawn as an active and critical subject, who can overcome obstacles to make school activities meaningful and, principally, productive. This means that, inside the teachers section, we can also find the figure of an enunciator subject that installs behavioral patterns in relation to teaching.

This idea of planning, marked by a strong argumentative discursivity, is reinforced inside the tab, where the linguistic text gives the reasons for designing a lesson plan and explains how to do it, at the same time that represents this educational practice (commonly associated with teachers) as if it was an inherent part of "human nature": "Planning is a human activity (...) It allows us to anticipate, foresee, organize and decide courses of action (...)".

Following and extending the considerations of Verón [18], who refers to different addressees in the political discourse, we can say that both the iconic component and the linguistic component of the text construct the figure of a para-addressee ${ }^{10}$, since the rhetorical-enunciative strategies tend to construct a persuasive discourse which alleged objectivity would convince teachers of the benefits of planning. This procedure implies two ways

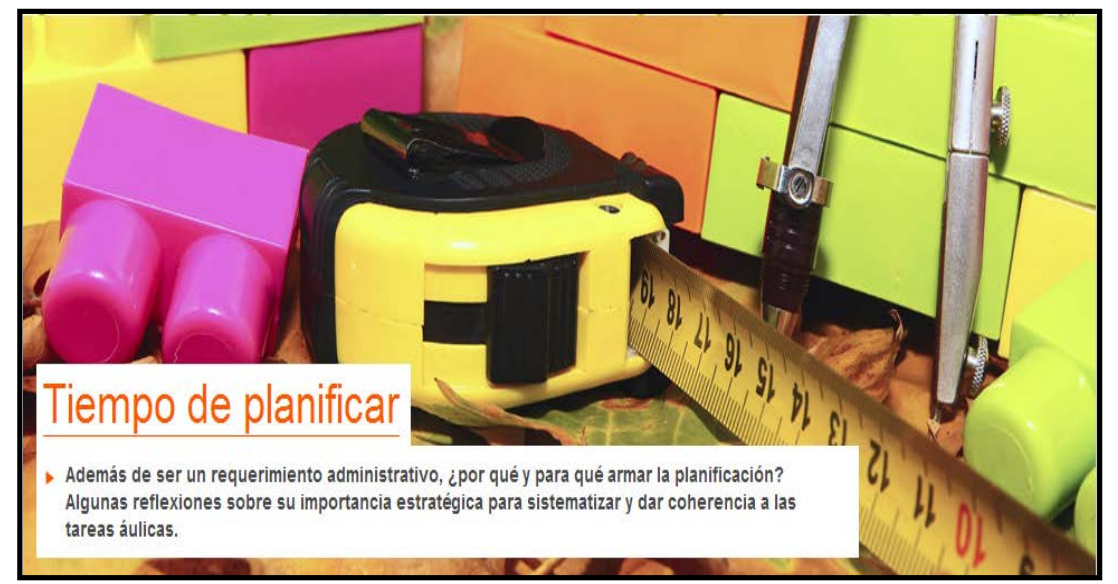

Figure 4. Screenshot of teacher's homepage.

\footnotetext{
${ }^{9}$ At present, we have only analysed the pages related to different types of users (families, students and teachers) because we consider that "news" and "TV" sections have similar characteristics that can be summarized in those segments.

${ }^{10}$ The author classifies three kinds of addressees: the "pro-addressee" (which includes different mechanisms that reinforce the shared belief), the "para-addressee" (which includes mechanisms on the order of persuasion) and the "counter-addressee" (which includes mechanisms on the order of polemical strategies).
} 
of discursive development: first, the use of a rhetorical syllogism or enthymeme, according to which the activity of planning is a human activity and, therefore, the human activities of teaching and learning require planning; and second, the addressee is based on the voice of those teachers who do not believe in planning in order to refute them: "How nice it would be if we could avoid planning".

This act of taking up the voice of certain teachers could be related to the concepts of "dialogic interaction" and "polyphony" developed by Bakhtin [19]. The Russian theorist says:

"(...) very frequently the expression of our utterance is determined not only -and sometimes not so much- by the referentially semantic content of this utterance, but also by others' utterances on the same topic to which we are responding or with which we are polemicizing” [19].

Then, the enunciator who assumes the figure of an "influencer" (Bremond [20]) develops a procedure consisting of introduction of "others' utterances" to "destroy" them and, also -in our case-, in order to modify or to adapt teachers' behavior. As we can see, the argumentative-pedagogical strategy that characterises the Educ.ar portal tries not only to provide conceptual resources, but also to teach models of behavior.

\subsection{The Family-Addressee}

The family-addressee section is indicated with the colour violet and it includes the following tabs: "school", "courses", "computer ideas" and "community". Here we can observe that linguistic texts carry out a function of relay (Barthes [21]) as they add meaning to images.

From Figure 5, we can see that there are three people of different ages using electronic devices: a child and an adult female using a laptop (a grandmother and her grandson); a woman with a tablet (the mother). Here, the school practice seems to be displaced to family life, private space and, possibly, leisure time. On the other hand, the linguistic text that accompanies the picture says: "Digital literacy in family. Not only kids use and introduce technological innovation into families, but we all work together to integrate them into our daily lives. The importance of sharing applications, skills and experiences between generations".

We can infer that this linguistic text tries to install the idea of incorporating family to the different technological processes. This is intensified under family's section, where we can find a number of resources that promote the idea of technology inclusion in the family, not only on the iconic level (by showing a family group in front of the computer), but also on the symbolic level (through the presence of different statements that invite reflections about this new social phenomenon): "It is always good to pay attention to what kids do. Sometimes, when we say that they are staring at a computer screen all day (...), we forget that they may be reading or learning through these devices (...)”.

The argumentative-pedagogical discourse expressed give some advice on the benefits offered by technologies in relation to teaching and learning processes, in order to eradicate the idea that "technologies are only useful to play". Here, the persuasive strategy unfolds on a two-way street: first, the enunciator tries to emphasize the idea

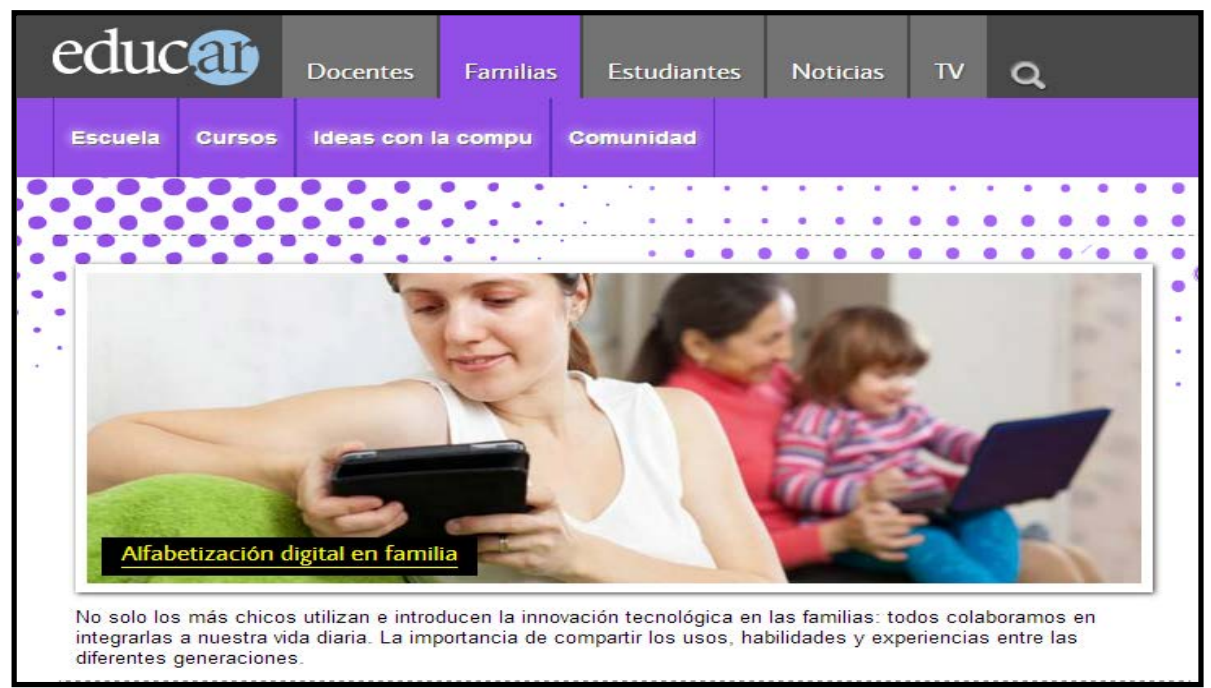

Figure 5. Screenshot of Family’s homepage. 
that uses of computer must not be associated with lost time; and second, it tries to configure a family model which helps children in the dynamics of technology integration.

This argumentative procedure can be demonstrated from the use of "inclusive we" (through which the enunciator tries to "lessen" the dogmatic nature of what it is considered as a valid statement) and also from the use of "bold", which highlights enunciator's view on what family should be as an institution: according to this figure, parents should know what their children do (to eventually regulate their behavior, since "it is always good to be aware of what kids do with technology"), but never have to become an obstacle to the development of their activities ("it is also good to help kids along the technological process"). In consequence, teaching is also extended to old people, stressing, in this case, the advantages that sharing technology with the family would have, at the same time the enunciator tries to install a behavioral habit that allows to relieve conflicts between generations. The enunciator makes statements of common sense ("we all work together to integrate technology into our daily life") and assumes a position as a teacher-enunciator, to the extent that it aims at teaching the family group how to behave in front of the emerging phenomenon of new technologies. And it becomes a guide too, who designs a daily life manual for students' parents.

\subsection{The Student-Addressee}

The student-addressee section is indicated with the colour blue and it includes the following tabs: "explore", "participate", "learn" and "blog". As we can see, most of those designations respond to the conative function of language (Jakobson [22]), at the same time they introduce an element that is not founded on the other sections: the use of "voseo" instead of "tuteo"11, which function would attenuate the asymmetry between teachers and students to promote a proximity effect through a colloquial register. Following the argumentative logic that overpass the educational portal, we can notice the existence of a particular dialogue between the enunciator and the addressee: while the first one is a figure that encourages searching and producing (that is, to "predispose" the addressee to enter in the scene), the second one not only searches and produces, but also seems to be able to "choose" tours:

From Figure 6, we can see that pictures are colourful and represent the stylistic modalities of a videogame. The linguistic text under the image says: "we present the challenges of Emilio, a game designed for students who won the Avatars competition in 2012". This discursive configuration that articulates indexical elements- to capture users' attention (through varied and illuminated colours) — with the expression "boys and girls like you" can motivate both creativity and practical (and funny) knowledge, and not only the acquisition of "encyclopedic content". In this case, we see a clear interest on transmitting information that goes beyond school content.

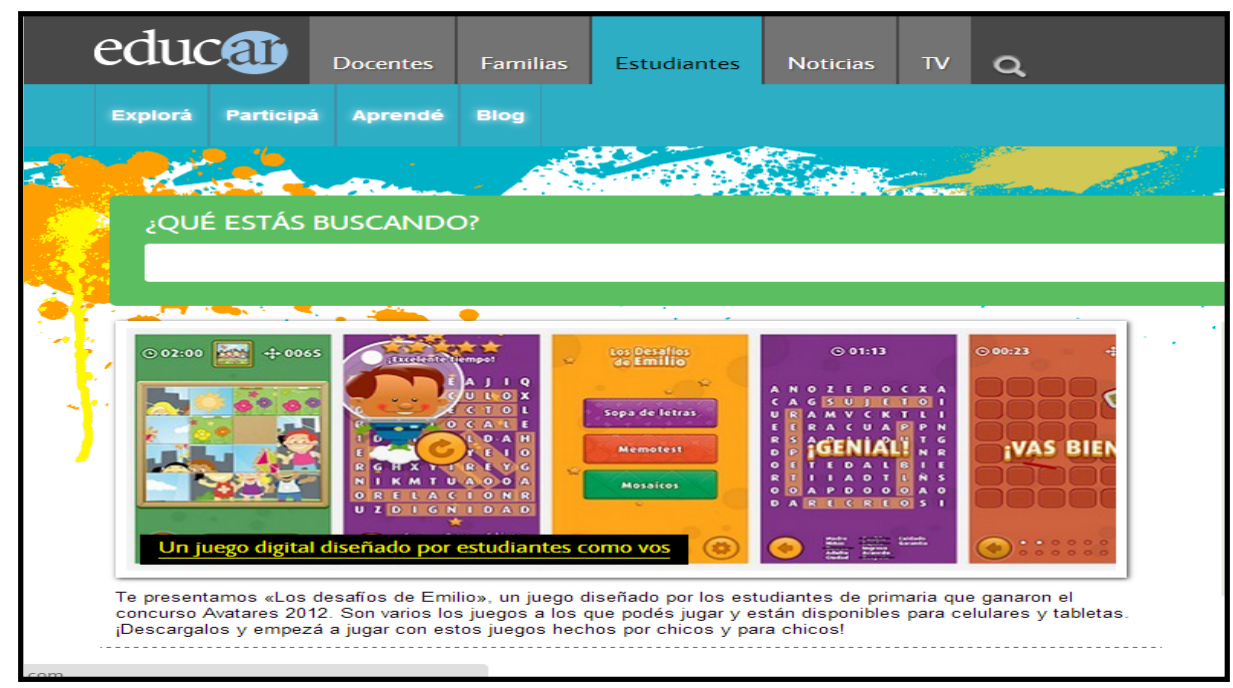

Figure 6. Screenshot of Student’s homepage.

\footnotetext{
${ }^{11}$ In Rioplatense Spanish, "voseo” is the use of "vos”, that is, an informal use of "you” in contrast with "usted”. On the other hand, "tuteo” is a hegemonic use of “you” in Standard Spanish. To expand this conceptualisation, read García Negroni \& Gelbes [23].
} 
The discursivity presented on this section proposes to stand out two aspects that have a correlate with the argumentative logic that we have been describing through this paper: on the one hand, we see an inclination to represent a "federal" teenager (students shown in pictures are not from the city center) and, on the other hand, there is a logic that consists on the idea of emphasising the figure of an "innovative subject". We notice a sort of interest to encourage the creativity of young users, in order to promote Argentine scientific and technological development. In this sense, the figure of "ideal-student" built refers to a young person that helps to the growth of the socio-economic and productive model.

Under this section there are various videos that include different testimonies from people related to the design and development of technology devices, in order to proof and encourage their existence. As the other users, the student-addressee is also configured as a "para-addressee" because the enunciator assigns it with a specific identity, defines its role and, also, persuades it: the image configured on Educ.ar portal is the image of a young man with a strong scientific vocation, who collaborates with and participates in the national productive development. Here we must ask: in this kind of image, is the representation of youth diverse? Are there plural identities? Could we think that all young people want to involve themselves with a scientific and technological vocation?

\section{Some Final Considerations: Suggestions for Improving the Discursive Organization of Educational Portals}

Throughout this paper, we tried to describe the discursive function of Educ.ar educational portal in order to shed some light on its rhetorical, thematic and enunciative strategies. Additionally, there were two reasons for our interest in carrying out this study: on the one hand, we wanted to identify the discursive procedures through which the structure of that digital platform was "organised"; on the other hand, we aimed to make some suggestions for optimising uses of educational portals and, therefore, contributing to its improvement. At this point we should ask whether this digital device has been being used in significant ways, that is, if we have been taking full advantage of its hypertext, multimedia, and interactive features. Based on these questions, we will now outline the limitations of Educ.ar portal in order to draw out some potential solutions to mitigate them.

Initially, we noticed that the "external" structure of Educ.ar presented some characteristics that could be related to textbooks, since it included a variety of educational levels (from primary to higher education) and different kinds of knowledge areas (from exact to humanistic disciplines). In this sense, its discursive strategies represent a double-edged sword because, although there is an intention to take advantage of multimedia device features and transcend the limitations imposed by analog media, there are certain restrictions on the organization and presentation of the materials. Furthermore, even though each addressee has a clearly "differentiated" space, Educ.ar homepage always begins with the "addressee-teacher", so it seems that there is a "privileged" addressee. This would lead other users - students and families—not to feel interpellated enough to use the platform according to their interests. Based on these considerations, it would be appropriate to design and include a generic homepage - which could be modified with respect to the school year, a selective homepage and a customised homepage dependent on each subject and user.

Another important issue is that most of the materials are distributed linearly and sequentially, for example, using the same thumbnail, which produces a "standardisation" effect. This is why it would be important to change that kind of configuration, placing elements all over the screen in a circular way and also improving the semantic precision of titles and captions, in order to give a specific identity to each document. Also, it would be necessary to include more interactive video games and not only related to "social interests" or "public safety". In addition to this, educational and recreational activities close to youth cultural consumption could be incorporated, either to problematise some social/cultural phenomena or to learn a particular concept/issue.

Regarding users' homepages, we also found some problems. In the case of the student-addressee, we noticed that the representation of young people was related to the idea of an innovative scientist who aspired to productive and technological knowledge. Under this section, we consider that it is important to differentiate age range (since "children", "teenagers" or "young people" are not the same subjects) and the specific issues and interests of audiences. Furthermore, we found that Educ.ar website was only linked to other digital devices that responded to the channels of the national state, when it could be also related to, for example, "Latin American voices", aiming to expand democratic and pluralistic discourses. In addition to this, we evidenced that the representations of "families" and "teachers" corresponded to the idea of "modeling" legitimated social behaviors: to encourage a responsible "pedagogical job", in the case of teachers, or to consolidate "harmonious" and "reciprocal" relations, 
in the case of families. In fact, we could indicate that if educational portals can be understood as devices designed to "put-off" and "disorientate" school knowledge in time and space (Martin-Barbero [24]; Scolari [25]), it would be necessary to address the discursive transformations that operate in the pedagogical discourse in order to avoid falling into a celebration of technology, as Buckingham says. This implies to reach a theoretical and methodological articulation which observes not only the most "optimistic" aspects of educational technology, but also the constraints and limitations that operates on it to optimise its genuine and meaningful pedagogical inclusion.

\section{Acknowledgements}

I gratefully acknowledge Professor Maria Rosa del Coto (University of Buenos Aires), Research Director, and financial support from the Secretary of Science and Technique (SECyT) dependant on the Faculty of Social Sciences (UBA, Argentina).

\section{References}

[1] Da Porta, E. (2011) Comunicación y Educación: algunas reflexiones para la búsqueda de nociones estratégicas. In: da Porta, E., Ed., Comunicación y educación: debates actuales desde un campo estratégico, Formación Docente, Córdoba, 41-60.

[2] Dussel, I. and Quevedo, L.A. (2010) Educación y nuevas tecnologías: Los desafíos pedagógicos ante el mundo digital. Actas del VI Foro latinoamericano de educación de la Fundación. Santillana, Buenos Aires, 1-78. http://virtualeduca.org/ifd/pdf/ines-dussel.pdf

[3] Puiggrós, A. (1995) Volver a educar. El desafío de la enseñanza argentina a finales del siglo XX. Ariel, Buenos Aires.

[4] Scolari, C. (2008) Hipermediaciones. Elementos para una Teoría de la Comunicación Digital Interactiva, Gedisa, Barcelona.

[5] Maggio, M. (2005) Los portales educativos: entradas y salidas a la educación del futuro. In: Tecnologías educativas en tiempos de Internet, Amorrortu, Buenos Aires.

[6] Sevillano García, M.L. (2010) Los contenidos en los portales educativos. TELOS, 84, 1-13. https://telos.fundaciontelefonica.com/url-direct/pdf-generator?tipoContenido=articuloTelos\&idContenido=2010072808 520001\&idioma $=\mathrm{es}$

[7] Martínez-Méndez, J., Martínez-Méndez, F. and López-Carreño, R. (2012) Portales educativos españoles: Revisión y análisis del uso de servicios Web 2.0. Investigación Bibliotecológica, 58, 47-69. http://www.scielo.org.mx/pdf/ib/v26n58/v26n58a3.pdf

[8] López-Guzmán, C. (2013) Los contenidos educativos en los contextos digitales. Revista Digital Universitaria, 14, 1-9. http://www.revista.unam.mx/vol.14/num2/art17/art17.pdf

[9] Castellón, L. and Jaramillo, O. (2013) Educación y videojuegos: Hacia un aprendizaje inmersivo. In: Scolari, C., Ed., Homo Videoludens 2.0: Del Pacman a la gamification, Barcelona, 264-281.

[10] Verón, E. (1993) La Semiosis Social. Fragmentos de una teoría de la discursividad. Gedisa, Barcelona.

[11] Peirce, C.S. (1978) Fragmentos de la ciencia de la semiótica. Nueva Visión, Buenos Aires.

[12] Steimberg, O. (1993) Semiótica de los Medios Masivos. El pasaje a los medios de los géneros populares. Atuel, Buenos Aires.

[13] Steimberg, O. (2013) Semióticas. Las semióticas de los géneros, de los estilos, de la transposición. Eterna Cadencia, Buenos Aires.

[14] Scolari, C. (2012) El texto DIY (Do It Yourself). In: Carlón, M. and Scolari, C.A., Eds., Colabor arte. Medios y artes en la era de la producción colaborativa, La Crujía, Buenos Aires, 21-42.

[15] Verón, E. (2013) La semiosis social 2. Ideas, momentos, interpretantes. Paidós, Buenos Aires.

[16] Giammateo, M. and Albano, H. (2012) El léxico. De la vida cotidiana a la comunicación cibernética. Biblos, Buenos Aires.

[17] Buckingham, D. (2008) Más allá de la tecnología. Aprendizaje infantil en la era de la cultura digital. Manantial, Buenos Aires.

[18] Verón, E. (2004) Fragmentos de un tejido. Gedisa, Barcelona.

[19] Bakhtin, M. (1998) Estética de la creación verbal. Siglo XXI, México D.F.

[20] Bremond, C. (1982) El rol del influenciador. In: Investigaciones retóricas II, Ediciones de Buenos Aires, Barcelona,. 
[21] Barthes, R. (1986) Lo obvio y lo obtuso: Imágenes, gestos, voces. Paidós, Barcelona.

[22] Jakobson, R. (1984) Ensayos de lingüística general. Ariel, Barcelona.

[23] García Negroni, M.M. and Ramírez, S. (2009) Acerca del voseo en los manuales escolares argentinos (1970-2004). In: Hummel, M., Kluge, B. and Laslop, M.E.V., Eds., Formas y fórmulas de tratamiento en el mundo hispano, El Colegio de México, México D.F., 1013-1032.

[24] Martín-Barbero, J. (2009) Cuando la tecnología deja de ser una ayuda didáctica para convertirse en mediación cultural. Revista Electrónica Teoría de la Educación, 10, 19-31.

http://campus.usal.es/ teoriaeducacion/rev_numero_10_01/n10_01_martin-barbero.pdf

[25] Scolari, C. (2016) Alfabetismo transmedia. Estrategias de aprendizaje informal y competencias mediáticas en la nueva ecología de la comunicación. TELOS, 103, 13-23.

https://telos.fundaciontelefonica.com/url-direct/pdf-generator?tipoContenido=articuloTelos\&idContenido=2016030812 $\underline{060001 \& i d i o m a}=\mathrm{es}$ 